Open Access

\title{
Erratum to: Heterogeneous expectations leading to bubbles and crashes in asset markets: Tipping point, herding behavior and group effect in an agent-based model
}

Sunyoung Lee and Keun Lee

* Correspondence: kenneth@snu.ac.kr Department of Economics, Seoul National University, Seoul, South Korea
This article was unintentionally published twice in this journal, by the same authors. The following should be considered the version of record and used for citation purposes: Sunyoung Lee and Keun Lee, Heterogeneous expectations leading to bubbles and crashes in asset markets: tipping point, herding behavior and group effect in an agent-based model, Journal of Open Innovation: Technology, Market and Complexity, 1:11, doi:10.1186/s40852-015-0014-8.

The duplicate: Sunyoung Lee and Keun Lee, Heterogeneous expectations leading to bubbles and crashes in asset markets: tipping point, herding behavior and group effect in an agent-based model, Journal of Open Innovation: Technology, Market and Complexity, 1:12, doi:10.1186/s40852-015-0013-9 is to be ignored.

Editor-in-Chief JinHyo Joseph Yun | Springer apologizes to the readers of the journal for not detecting the duplication during the publication process.

Submit your manuscript to a SpringerOpen ${ }^{\odot}$ journal and benefit from:

- Convenient online submission

- Rigorous peer review

- Immediate publication on acceptance

- Open access: articles freely available online

- High visibility within the field

- Retaining the copyright to your article

Submit your next manuscript at springeropen.com 